\title{
SCREENING OF PHYTOCHEMICAL CONTENT AND IN VITRO BIOLOGICAL INVESTIGATION OF CANTHIUM DICOCCUM (GAERTN.) AND AMISCHOPHACELUS AXILLARIS (L.)
}

\author{
MEGHASHREE K S, LATHA K P*, VAGDEVI H M, AJISH A D, JAYANNA N D, ARUNKUMAR N C \\ Department Chemistry, Sahyadri Science College, Shimoga, Karnataka, India. Email: lathakp337@gmail.com
}

Received: 28 October 2019, Revised and Accepted: 16 November 2019

\begin{abstract}
Objective: The objective of the study was to study the pet ether, ethyl acetate, and ethanol leaf extracts of Canthium dicoccum and Amischophacelus axillaris for anthelmintic activity and antihypertensive activity.
\end{abstract}

Methods: The antihypertensive activity was carried out by employing a colorimetric assay based on the hydrolysis of Histidyl-Hippuryl-Leucine and anthelmintic activity carried out against Indian earthworm Pheritimaposthuma.

Results: The pet ether leaf extract both the plants exhibited the maximum antihypertensive activity with a percent inhibition of 64.82 for $C$. dicoccum (Gaertn.) and 84.12 for A. axillaris (L.) as compared with Captopril showing percent inhibition 85.37 and for anthelmintic activity, it is found that ethanol extract of $C$. dicoccum and ethyl acetate extract of $A$. axillaris exhibited significant activity against the standard drug albendazole.

Conclusion: This study investigated the potential of $C$. dicoccum and A. axillaris as a new source against the antihypertensive activity. The outcome of anthelmintic activity revealed that the ethyl acetate and ethanol extracts exhibited a considerable amount of anthelmintic activity, which is mainly due to the active phytoconstituents present in the extracts.

Keywords: Antihypertensive, Anthelmintic, Canthium dicoccum (Gaertn.), Amischophacelus axillaris (L.), Angiotensin-Converting Enzyme inhibitors.

(C) 2020 The Authors. Published by Innovare Academic Sciences Pvt Ltd. This is an open access article under the CC BY license (http://creativecommons. org/licenses/by/4. 0/) DOI: http://dx.doi.org/10.22159/ajpcr.2020.v13i1.36200

\section{INTRODUCTION}

Hypertension is nowadays common among people of all age groups. It does not give any early warning symptoms, but it exerts more load on heart and blood vessels due to which it is termed as a silent killer. Immense importance has been given to the study of hypertension with the development of a realistic method to measure it in the past century due to constant change in the lifestyle of people. Physicians have been working tirelessly to ascertain the relation between high blood pressure and risk of failure of heart, kidney, and even causes a stroke. Some early attempts in 1930s and 40s, including surgical procedures involving cutting nerves to blood vessels, inducing high fever and reducing sodium content in diets. Few case studies have yielded significant results proving the treatments are effective in lowering blood pressure and improving outcomes with minor setbacks. One of the proved methods of treatment of hypertension apart from drugs is by improving lifestyle and standard of living. The method of treatment associated with dietary and lifestyle measures considerably reduces the arterial pressure thereby mitigates cardiovascular morbidity and mortality [1-4]. Search for new drugs, mainly from cheap and reliable natural products, and mainly plants are of significant interest in the development of more efficient and better-tolerated drugs. Therefore, it is relatively essential to study the inhibition of angiotensin-converting enzyme (ACE) to prevent and manage hypertension. Macroparasitic disease caused by parasitic worms that are visible to naked eye affecting humans as well as other animals wherein a part of the body or an organ is infected by the worm is known as helminths. Presently, helminthiasis is one of the common agents of infection rampantly prevailing in developing as well as underdeveloped countries. The spread of helminthiasis which is a significant contributor to global diseases is worsened by prevailing malnutrition, pneumonia, anemia, and eosinophilia in underdeveloped countries [5] due to the nonavailability of basic health infrastructure and medically trained personnel to handle the situations. Helminthiasis is rarely fatal but is a major cause of morbidity [6]. The medicines available in the market which are chemically synthesized are not effective up to the mark and in some cases have developed resistance thereby causing reoccurrences of the diseases. Thus medicinal plants which are rich in botanical anthelmintics $[7,3]$ serve as an alternate source for the development of more effective and less toxic medicines which has encouraged further research and development in analyzing new plant-derived medicines.

Canthium dicoccum (Gaertn.), the Ceylon boxwood also known as Bellachi in Kannada, belongs to the family Rubiaceae [8]. In India, its bark is used for fever and decoction of the root is used internally for diarrhea. Bark powder with sesame oil is used in rheumatic pain $[9,10]$. The plant is proved for its anti-inflammatory [11], antidiabetic, and nephroprotective activity [12].

Amischophacelus axillaris (L.) is a species of perennial plants in the family Commelinaceae commonly called Negilu there in Kannada. It is native to the Indian Subcontinent, southern China, South East Asia, and Northern Australia. It grows in monsoon forest, woodland, and wooded grassland. Traditionally plant is used for anti-inflammatory, antiparasitic, and antifungal property. In India, leaves are used for the treatment of tympanitis and as food for pigs [13].

\section{METHODS}

The $C$. dicoccum (Gaertn.) leaves were collected in the month of JuneJuly in Hosnagar (T), Fig. 1 Shimoga district, Karnataka, and A. axillaris (L.) Fig. 2 leaves were collected in the month of July-August in Agumbe region, Shimoga district, Karnataka. Both the plants were authenticated and deposited in the Department of Botany Kuvempu University, Shankaraghatta, with voucher number KUAB4688 for C. dicoccum (Gaertn.) and KUAB4687 for A. axillaris (L.). The collected plant material was shade dried and coarsely pulverized. The pulverized plant material was subjected to the hot method of extraction using Soxhlet extractor. The extraction method was carried out using numerous solvents, namely, pet ether, ethyl acetate, and ethanol per their 
increasing polarity. The obtained extract was filtered and evaporated to dryness under reduced pressure in a rotary vacuum evaporator.

\section{Qualitative phytochemical screening}

All the extracts were subjected to preliminary phytochemical analysis using the standard procedure to identify the various phytoconstituents [14].

\section{Antihypertensive activity}

The plant extracts were tested at three concentrations dissolved in assay buffer (10 mM (4-(2-hydroxyethyl)-1-piperazineethanesulfonic acid) HEPES buffer containing $0.3 \mathrm{M} \mathrm{NaCl}$ and $10 \mu \mathrm{M}$ Zinc Sulfate) containing $20 \mu \mathrm{l}$ of kidney cortex plasma membranes (ACE enzyme source) and $1 \mathrm{mM}$ Hippuryl-His-Leuas substrate. The extracts were incubated with the enzyme for $10 \mathrm{~min}$ at $37^{\circ} \mathrm{C}$. The substrate was added to the reaction mixture and incubated for $45 \mathrm{~min}$ at $37^{\circ} \mathrm{C}$. The reaction was terminated by the addition of $1 \mathrm{M} \mathrm{HCl}$. The yellow color is developed by the addition of $100 \mu \mathrm{l}$ of pyridine and $50 \mu \mathrm{l}$ of benzene sulfonyl chloride and was measured at $410 \mathrm{~nm}$ in an ELISA Plate Reader (iMARK, BIORAD). The extract block availability of substrate to the enzyme and thereby cause enzyme inhibition, by indicating no formation of yellow color. The inhibition was represented in the form of a percentage over control. Captopril, a known ACE inhibitor was tested in this assay as a standard compound $[15,16]$. The inhibition activity was calculated using the following equation

Inhibition activity $(\%)=\left[\left(A_{c}-A_{s} /\left(A_{c}-A_{b}\right)\right] \times 100\right.$

Where, $A_{c}$ is the absorbance of the buffer (control), $A_{s}$ is the absorbance of the reaction mixture (sample), $A_{b}$ is the absorbance when the stoke solution was added before the reaction occurred (blank).

\section{Anthelmintic activity}

Indian adult earthworms Pheritimaposthuma were collected from earthworm rearing center, Dummalli, Shimoga (Karnataka). The worms were maintained in the cages with moderate temperatures. The worms were washed in water to remove dirt. The anthelmintic activity was evaluated on Indian adult earthworms Pheritimaposthuma due to its anatomical and physiological resemblances with the intestinal roundworm parasites of the human beings $[17,18]$. The activity was assessed using earthworms by the reported methods with small modifications [19]. The worms were washed to get rid of adhering materials and were sorted out for uniform size and length. The worms were kept in a $6 \%$ dextrose solution for acclimatization. The worms with normal motility of length having 3-5 $\mathrm{cm}$ and $0.1-0.2 \mathrm{~mm}$ in width were used for the experiment. All the worms of equal size were divided into 11 groups and each group contains three worms. I group was treated with vehicle (1\% Tween-80 in normal saline) served as control, II group is treated with albendazole (Standard) $10 \mathrm{mg} / \mathrm{ml}$, and III - XI groups were treated with different concentrations $(20,40$, and $60 \mathrm{mg} / \mathrm{ml}$ in normal saline containing 1\% Tween-80) of all the three extracts. Observations were made for the time taken to paralysis and death of individual worm. Paralysis was said to occur when the normal group did not survive in the saline. Death was concluded when the worm lost its motility followed by the fading of their body color. The experiment was carried out in triplicate for each group and data were statistically analyzed.

\section{RESULTS}

Results showed pronounced activity for pet ether extract with percent inhibition of 64.82 for $C$. dicoccum (Table 1, Fig. 3) and 84.12 for A. axillaris (Table 2, Fig. 4). These activities are comparable with the activity of the positive control, captopril, which has a percent inhibition of 85.37. The preliminary evaluation of the crude extracts of $C$. dicoccum and $A$. axillaris showed that both the plants are a potential source of bioactive compounds that can inhibit the activity of ACE. The pet ether

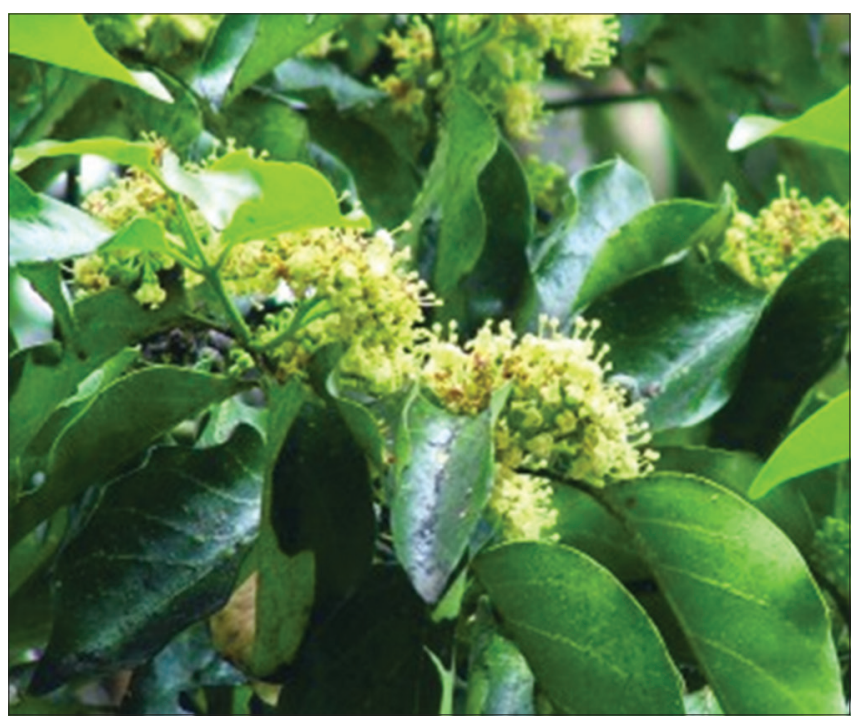

Fig. 1: Canthium dicoccum (Gaertn.) plant

Table 1: Antihypertensive activity of various solvent extracts of Canthium dicoccum (Gaertn.) leaves with standard

\begin{tabular}{|c|c|c|c|c|}
\hline Samples & Concentration & O.D. & OD-Blank & $\%$ ACE inhibition \\
\hline Blank & & 0.405 & & \\
\hline \multirow[t]{3}{*}{ Control } & & 0.985 & 0.580 & \\
\hline & $20 \mu \mathrm{g}$ & 0.773 & 0.368 & $36.552 \pm 1.194$ \\
\hline & $40 \mu \mathrm{g}$ & 0.740 & 0.335 & $42.241 \pm 0.000$ \\
\hline \multirow[t]{4}{*}{ A } & $60 \mu \mathrm{g}$ & 0.687 & 0.282 & $50.977 \pm 0.583$ \\
\hline & $80 \mu \mathrm{g}$ & 0.680 & 0.275 & $56.264 \pm 5.119$ \\
\hline & $100 \mu \mathrm{g}$ & 0.609 & 0.204 & $64.827 \pm 0.895$ \\
\hline & $40 \mu \mathrm{g}$ & 0.652 & 0.247 & $57.414 \pm 0.298$ \\
\hline \multirow[t]{5}{*}{ B } & $60 \mu \mathrm{g}$ & 0.789 & 0.384 & $33.793 \pm 0.597 *$ \\
\hline & $80 \mu \mathrm{g}$ & 0.772 & 0.367 & $36.724 \pm 0.896$ \\
\hline & $100 \mu \mathrm{g}$ & 0.758 & 0.353 & $39.138 \pm 0.497$ \\
\hline & $20 \mu \mathrm{g}$ & 0.776 & 0.371 & $36.034 \pm 0.597$ \\
\hline & $40 \mu \mathrm{g}$ & 0.844 & 0.439 & $24.310 \pm 0.696^{* *}$ \\
\hline \multirow[t]{2}{*}{$\mathrm{C}$} & $60 \mu \mathrm{g}$ & 0.954 & 0.549 & $5.344 \pm 0.597^{* *}$ \\
\hline & $80 \mu \mathrm{g}$ & 0.974 & 0.569 & $2.011 \pm 0.897^{* *}$ \\
\hline \multirow[t]{2}{*}{$\mathrm{D}$} & $15 \mathrm{nM}$ & 0.412 & 0.211 & $51.966 \pm 1.134$ \\
\hline & $25 \mathrm{nM}$ & 0.268 & 0.067 & $85.370 \pm 0.883$ \\
\hline
\end{tabular}

Significance level: The data were analyzed using ANOVA and expressed as Mean \pm SEM followed by Dunnett's test and differences between means were regarded significant at $\mathrm{p}<0.05^{*}, \mathrm{p}<0.01^{* *}$, C. dicoccum: Canthium dicoccum, SEM: Standard error of the mean, ANOVA: Analysis of variance, OD: Optical density 
extract of both the plants was found to have the highest ACE inhibitory activity. Further purification studies will be carried out to identify the bioactive compounds responsible for the observed activity.

For anthelmintic activity, the time is taken for mean paralysis and means the death of the earthworms are tabulated in Tables 3 and 4 . The main

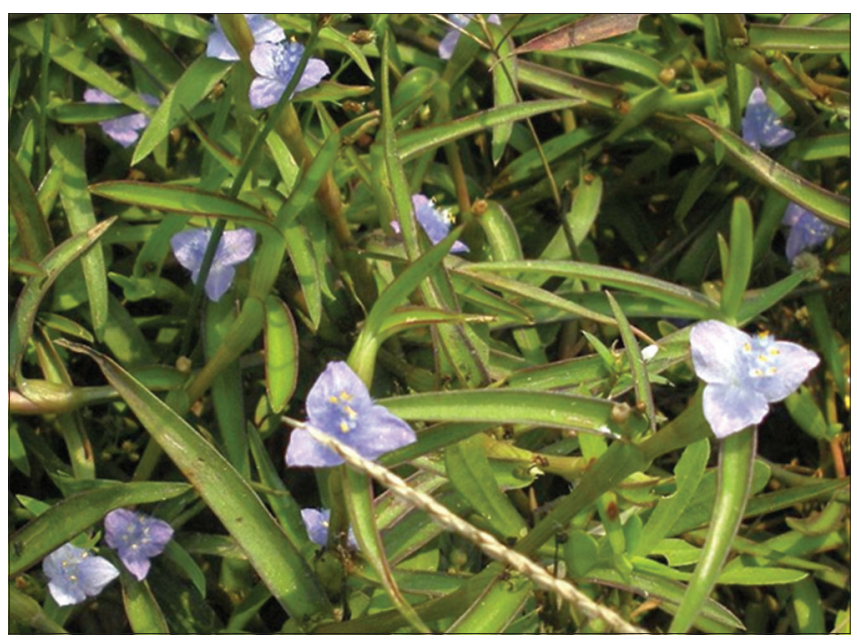

Fig. 2: Amischophacelus axillaris (L.) plant effect of albendazole on the worm is to cause a flaccid paralysis that effects in exclusion of the worm by peristalsis. The data of the present study revealed that all the tested extracts of $C$. dicoccum (Gaertn.) and A. axillaris (L.) have anthelmintic activity in dose-dependent method giving the shortest time of paralysis and death of worms. The results showed that the ethanol extract of $C$. dicoccum (Gaertn.) and ethyl acetate extract of $A$. axillaris (L.) exhibited considerable anthelmintic activity at a concentration of $60 \mathrm{mg} / \mathrm{ml}$ by causing the death of worms in lesser time. The anthelmintic activity of all the extracts was comparable to that of the standard drug albendazole. Preliminary phytochemical screening of crude extracts of $C$. dicoccum and $A$. axillaris revealed that the presence of various phytochemical constituents is tabulated in Tables 5 and 6.

\section{DISCUSSION}

A reference study showed that pet ether extract of $C$. dicoccum contains high concentration of phenolic compounds [20]. The free hydroxyl groups of phenolic compounds are the structural moieties that chelate zinc ions in the active site of ACE thereby rendering ACE inactive [21]. The present results showed that both $C$. dicoccum and A. axillaris showed a high concentration of phenolic groups, which is the major moiety to rendering ACE inactive. Some of the secondary metabolites that could be responsible for the observed in vitro ACE inhibitory activity are steroids, flavonoids, glycosides, and hydrolyzable tannins. The results of the phytochemical screening revealed the presence of alkaloids, terpenes, flavonoids, tannins, anthraquinones, and saponins in C. dicoccum extract [20]. Elbl and Wagner developed one of the earliest

Table 2: Antihypertensive activity of various solvent extracts of Amischophacelus axillaris (L.) leaves with standard

\begin{tabular}{|c|c|c|c|c|}
\hline Samples & Concentration & O.D & OD-Blank & $\%$ ACE inhibition \\
\hline Blank & & 0.308 & & \\
\hline \multirow[t]{3}{*}{ Control } & & 0.914 & 0.693 & \\
\hline & $20 \mu \mathrm{g}$ & 0.527 & 0.219 & $68.398 \pm 0.416$ \\
\hline & $40 \mu \mathrm{g}$ & 0.541 & 0.233 & $66.378 \pm 0.831$ \\
\hline \multirow[t]{4}{*}{ A } & $60 \mu \mathrm{g}$ & 0.498 & 0.190 & $72.583 \pm 0.166$ \\
\hline & $80 \mu \mathrm{g}$ & 0.412 & 0.104 & $84.993 \pm 0.833^{* *}$ \\
\hline & $100 \mu \mathrm{g}$ & 0.418 & 0.110 & $84.127 \pm 0.249 * *$ \\
\hline & $40 \mu \mathrm{g}$ & 0.544 & 0.236 & $44.589 \pm 0.333$ \\
\hline \multirow[t]{5}{*}{$\mathrm{B}$} & $60 \mu \mathrm{g}$ & 0.534 & 0.226 & $45.021 \pm 0.416$ \\
\hline & $80 \mu \mathrm{g}$ & 0.512 & 0.204 & $47.474 \pm 0.916$ \\
\hline & $100 \mu \mathrm{g}$ & 0.501 & 0.193 & $49.495 \pm 0.249$ \\
\hline & $20 \mu \mathrm{g}$ & 0.639 & 0.331 & $61.327 \pm 0.166$ \\
\hline & $40 \mu \mathrm{g}$ & 0.692 & 0.384 & $65.945 \pm 0.499$ \\
\hline \multirow[t]{3}{*}{$\mathrm{C}$} & $60 \mu \mathrm{g}$ & 0.689 & 0.381 & $67.388 \pm 0.499$ \\
\hline & $80 \mu \mathrm{g}$ & 0.672 & 0.364 & $70.562 \pm 0.416$ \\
\hline & $10 \mathrm{nM}$ & 0.506 & 0.305 & $33.410 \pm 0.756$ \\
\hline \multirow[t]{2}{*}{$\mathrm{D}$} & $15 \mathrm{nM}$ & 0.412 & 0.211 & $51.966 \pm 1.134$ \\
\hline & $25 \mathrm{nM}$ & 0.268 & 0.067 & $85.370 \pm 0.883$ \\
\hline
\end{tabular}

Significance level: The data were analyzed using ANOVA and expressed as Mean \pm SEM followed by Dunnett's test and differences between means were regarded significant at $\mathrm{p}<0.05^{*}, \mathrm{p}<0.01^{* *}$, A. axillaris(L.): Amischophacelus axillaris (L.), SEM: Standard error of the mean, ANOVA: Analysis of variance, OD: Optical density

Table 3: Anthelmintic activity of various solvent extracts of Canthium dicoccum (Gaertn.) leaves with standard

\begin{tabular}{|c|c|c|c|}
\hline Treatment groups & Concentration (mg/ml) & Mean paralysis time $(\mathrm{min}) \pm \mathrm{SEM}$ & Mean death time (min) \pm SEM \\
\hline Control/Vehicle & & --------- & --------- \\
\hline \multirow[t]{2}{*}{ Standard } & 10 & $7.13 \pm 0.008$ & $13.09 \pm 0.039$ \\
\hline & 20 & $14.13 \pm 0.20$ & $22.13 \pm 0.014$ \\
\hline \multirow[t]{2}{*}{ A } & 40 & $12.12 \pm 0.023$ & $20.10 \pm 0.017$ \\
\hline & 60 & $10.08 \pm 0.017$ & $20.08 \pm 0.020$ \\
\hline \multirow[t]{4}{*}{ B } & 20 & $12.14 \pm 0.012$ & $24.10 \pm 0.008$ \\
\hline & 40 & $10.06 \pm 0.026$ & $22.13 \pm 0.026$ \\
\hline & 60 & $10.10 \pm 0.015$ & $18.12 \pm 0.011$ \\
\hline & 20 & $12.06 \pm 0.008$ & $15.10 \pm 0.008$ \\
\hline \multirow[t]{2}{*}{$\mathrm{C}$} & 40 & $9.09 \pm 0.020$ & $18.14 \pm 0.014$ \\
\hline & 60 & $9.08 \pm 0.008$ & $16.15 \pm 0.017$ \\
\hline
\end{tabular}

Significance level: The data were analyzed using ANOVA and expressed as Mean \pm SEM followed by Dunnett's test and differences between means were regarded significant at $\mathrm{p}<0.05^{*}, \mathrm{p}<0.01^{* *}$, C. dicoccum: Canthium dicoccum, SEM: Standard error of the mean, ANOVA: Analysis of variance 


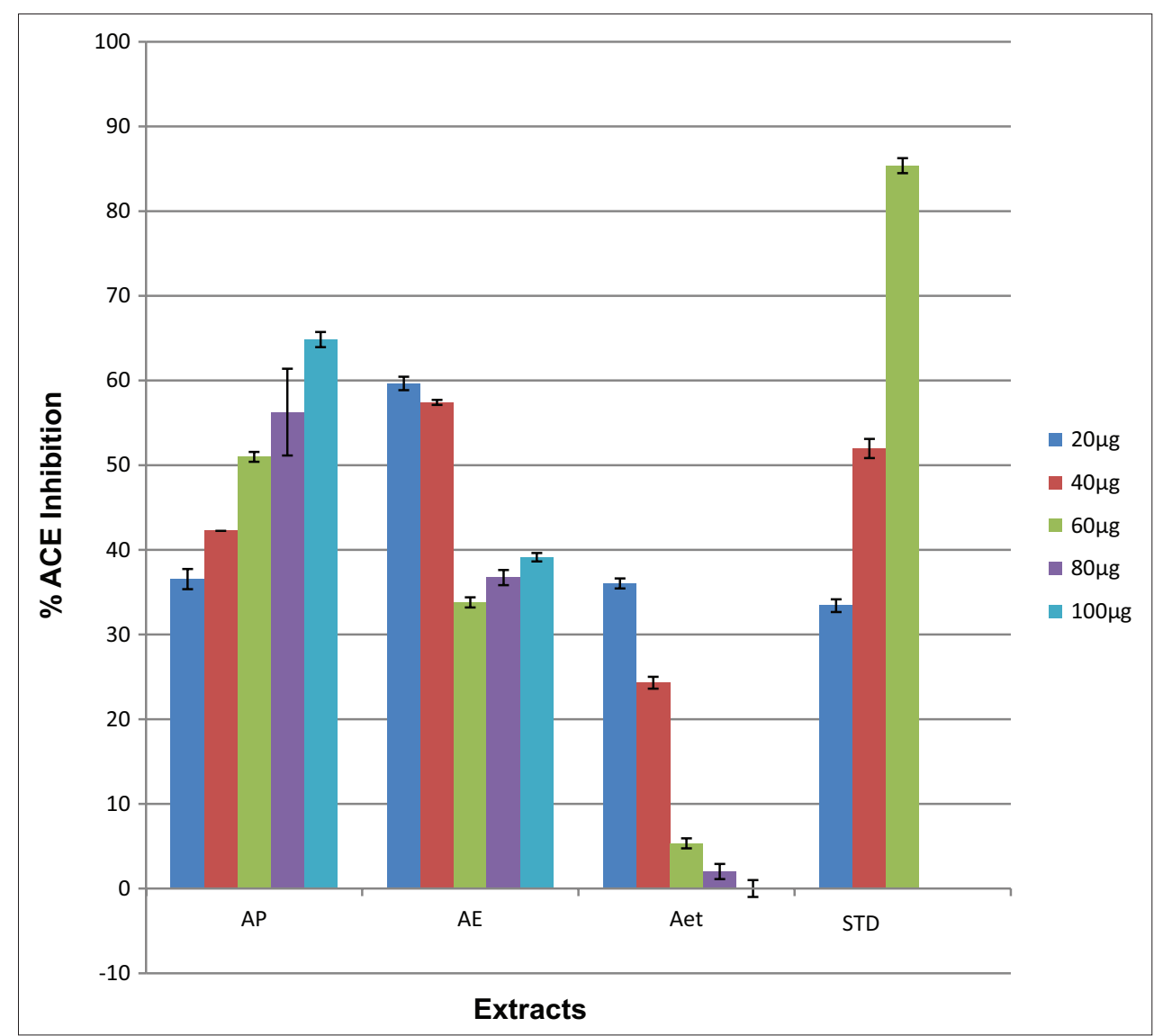

Fig. 3: Antihypertensive activity of Canthium dicoccum (Gaertn.) of various solvent extracts in angiotensin-converting enzyme inhibitors method. AP- pet ether extract, AE- ethyl acetate extract, Aet- ethanol extract, STD: Standard, Standard = Captopril in $10 \mathrm{nM}, 15 \mathrm{nM}, 25 \mathrm{nM}$

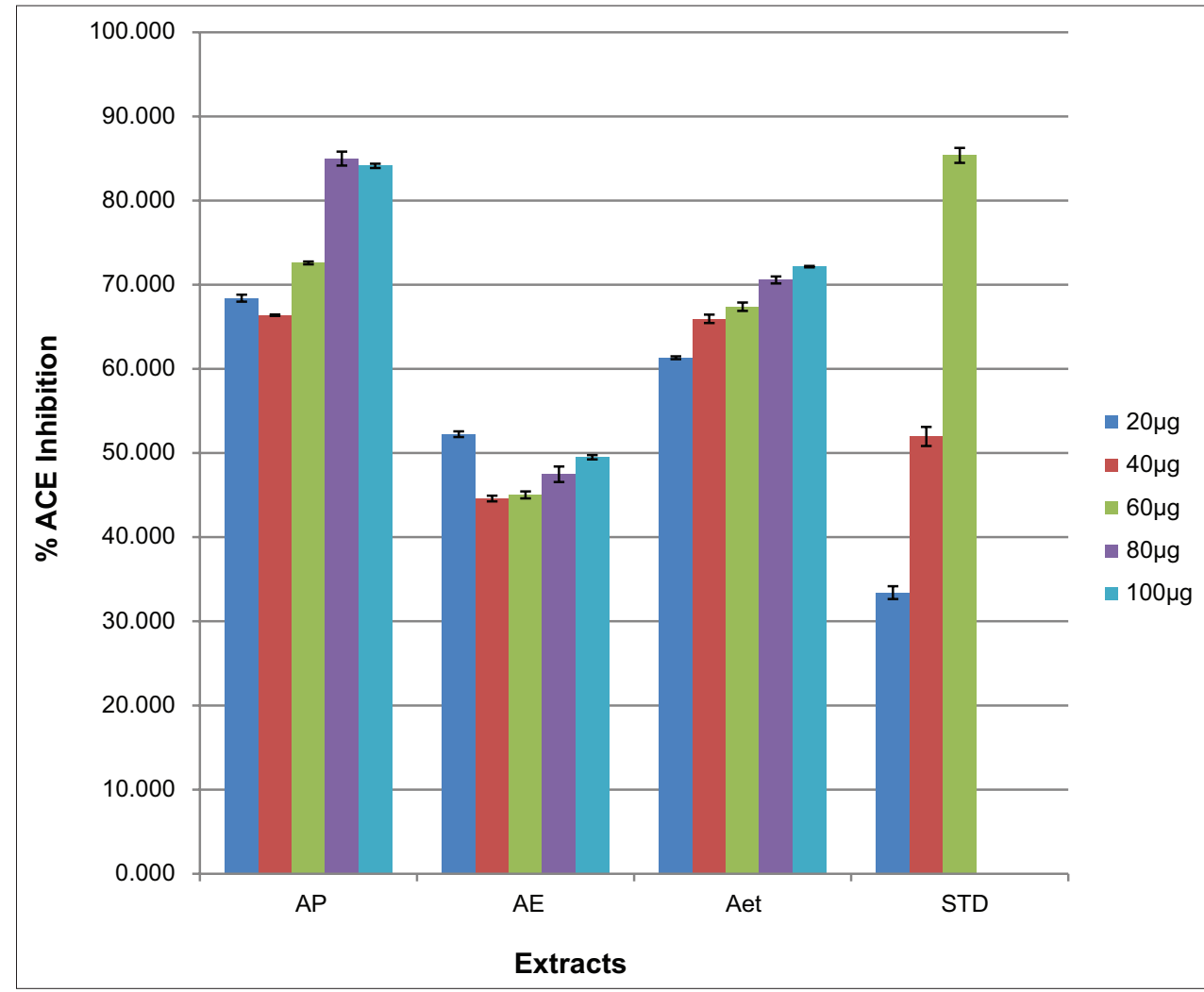

Fig. 4: Antihypertensive activity of Amischophacelus axillaris (L.) of various solvent extracts in angiotensin-converting enzyme inhibitors method. AP- pet ether extract, AE- ethyl acetate extract, Aet- ethanol extract, STD - standard. Standard = Captopril in $10 \mathrm{nM}, 15 \mathrm{nM}, 25 \mathrm{n}$ 
Table 4: It shows anthelmintic activity of different extracts of Canthium dicoccum (Gaertn.) and Amischophacelus axillaris (L.) leaves with standard

\begin{tabular}{|c|c|c|c|}
\hline Treatment groups & Concentration $(\mathrm{mg} / \mathrm{ml})$ & Mean paralysis time (min) $\pm S E M$ & Mean death time (min) \pm SEM \\
\hline Control/Vehicle & & --------- & --------- \\
\hline \multirow[t]{2}{*}{ Standard } & 10 & $7.13 \pm 0.008$ & $13.09 \pm 0.039$ \\
\hline & 20 & $18.09 \pm 0.005$ & $22.14 \pm 0.012$ \\
\hline \multirow[t]{2}{*}{ A } & 40 & $15.10 \pm 0.008$ & $20.09 \pm 0.005$ \\
\hline & 60 & $13.14 \pm 0.014$ & $18.11 \pm 0.008$ \\
\hline \multirow[t]{4}{*}{ B } & 20 & $17.11 \pm 0.008$ & $23.08 \pm 0.005$ \\
\hline & 40 & $10.08 \pm 0.014$ & $20.11 \pm 0.020$ \\
\hline & 60 & $9.05 \pm 0.012$ & $15.05 \pm 0.026$ \\
\hline & 20 & $16.14 \pm 0.015$ & $21.14 \pm 0.028$ \\
\hline \multirow[t]{2}{*}{$\mathrm{C}$} & 40 & $15.03 \pm 0.173$ & $20.01 \pm 0.046$ \\
\hline & 60 & $13.02 \pm 0.023$ & $18.02 \pm 0.00$ \\
\hline
\end{tabular}

Significance level: The data were analyzed using ANOVA and expressed as Mean \pm SEM followed by Dunnett's test and differences between means were regarded significant at $\mathrm{p}<0.05^{*}, \mathrm{p}<0.01^{* *}$, A. axillaris (L.): Amischophacelus axillaris (L.), SEM: Standard error of the mean, ANOVA: Analysis of variance

Table 5: Phytochemical screening of various solvent extracts of Canthium dicoccum (Gaertn.) leaves

\begin{tabular}{llll}
\hline Phytoconstituents & $\begin{array}{l}\text { Pet. ether } \\
\text { extract }\end{array}$ & $\begin{array}{l}\text { Ethyl acetate } \\
\text { extract }\end{array}$ & $\begin{array}{l}\text { Ethanol } \\
\text { extract }\end{array}$ \\
\hline Alkaloids & $-\mathrm{ve}$ & $+\mathrm{ve}$ & $+\mathrm{ve}$ \\
Steroids & $-\mathrm{ve}$ & $+\mathrm{ve}$ & $+\mathrm{ve}$ \\
Carbohydrates & $+\mathrm{ve}$ & $+\mathrm{ve}$ & $+\mathrm{ve}$ \\
Flavonoids & $-\mathrm{ve}$ & $+\mathrm{ve}$ & $-\mathrm{ve}$ \\
Phenolics/Tannins & $+\mathrm{ve}$ & $+\mathrm{ve}$ & $+\mathrm{ve}$ \\
Saponins & $+\mathrm{ve}$ & $+\mathrm{ve}$ & $+\mathrm{ve}$ \\
Glycosides & $-\mathrm{ve}$ & $+\mathrm{ve}$ & $+\mathrm{ve}$ \\
Coumarin & $-\mathrm{ve}$ & $+\mathrm{ve}$ & $+\mathrm{ve}$ \\
\hline
\end{tabular}

Table 6: Phytochemical screening of various solvent extracts of Amischophacelus axillaris (L.) leaves

\begin{tabular}{llll}
\hline Phytoconstituents & $\begin{array}{l}\text { Pet. ether } \\
\text { extract }\end{array}$ & $\begin{array}{l}\text { Ethyl acetate } \\
\text { extract }\end{array}$ & $\begin{array}{l}\text { Ethanol } \\
\text { extract }\end{array}$ \\
\hline Alkaloids & $-\mathrm{ve}$ & $+\mathrm{ve}$ & $+\mathrm{ve}$ \\
Steroids & $-\mathrm{ve}$ & $+\mathrm{ve}$ & $+\mathrm{ve}$ \\
Carbohydrates & $+\mathrm{ve}$ & $+\mathrm{ve}$ & $+\mathrm{ve}$ \\
Flavonoids & $+\mathrm{ve}$ & $+\mathrm{ve}$ & $-\mathrm{ve}$ \\
Phenolics/Tannins & $+\mathrm{ve}$ & $+\mathrm{ve}$ & $+\mathrm{ve}$ \\
Saponins & $+\mathrm{ve}$ & $+\mathrm{ve}$ & $+\mathrm{ve}$ \\
Glycosides & $+\mathrm{ve}$ & $-\mathrm{ve}$ & $+\mathrm{ve}$ \\
Coumarin & $-\mathrm{ve}$ & $+\mathrm{ve}$ & $+\mathrm{ve}$ \\
\hline
\end{tabular}

assays for ACE inhibition, stated that an extract is considered active if it is able to inhibit the enzyme by more than $50 \%[22,23]$. The pet ether extract of $C$. dicoccum and ethanol extract of $A$. axillaris plant showed proper inhibition of more than $50 \%$ result when compared with the standard drug. In the anthelmintic activity, the ethanol and ethyl acetate extracts of both the plant not only established paralysis but also caused the death of worms, particularly, at a higher concentration of $60 \mathrm{mg} / \mathrm{ml}$ in a shorter time as compared to that of albendazole. Phytochemical screening of the extracts showed the presence of flavonoids, alkaloids, steroids, and tannins [24]. Polyphenolic compounds were mainly present in tannins; these compounds are the main reason to show anthelmintic activities $[25,26]$. Phytochemical screening showed the presence of tannins in the plant extracts (Tables 5 and 6). Tannins can bind to free proteins in the gastrointestinal tract of host animals that may lead to death. Local healers from Karnataka used Canthium species and A. axillaris (L.) for many medicinal purposes, these plants are unknown as an antihypertensive and anthelmintic agent.

\section{CONCLUSION}

The present study suggests that the leaves of $C$. dicoccum and A. axillaris possess ACE inhibitory that might be helpful in treating hypertension.
Further investigations on the isolation of active compounds present in the extracts and in vivo studies are essential to identify a potential chemical entity for clinical use in the treatment of hypertension and further related cardiovascular disorders. This study investigated the potential of $C$. dicoccum and A. axillaris as a new source against ACE. The outcome of anthelmintic activity revealed that the ethyl acetate and ethanol extracts exhibited a considerable amount of anthelmintic activity, which is mainly due to the active phytoconstituents present in the extracts. The present study gives proof that it may be a productive medicine in the upcoming days. Further, the plant extracts will be explored for its phytochemical outline to identify the active component, which is responsible for anthelmintic activity.

\section{AUTHOR'S CONTRIBUTIONS}

All authors have equally contributed to making this report to be successful.

\section{CONFLICTS OF INTEREST}

There are no conflicts of interest.

\section{REFERENCES}

1. Amery A, Birkenhäger W, Brixko P, Bulpitt C, Clement D, Deruyttere M, et al. Mortality and morbidity results from the European working party on high blood pressure in the elderly trial. Lancet 1985;1:1349-54.

2. Dahlöf B, Lindholm LH, Hansson L, Scherstén B, Ekbom T, Wester PO. Morbidity and mortality in the Swedish Trial in Old Patients with Hypertension (STOP-Hypertension) Lancet 1991;338:1281-5.

3. Lewis WH, Lewis MP. Medicinal Botany Plants Affecting Man's Health. New York: John Wiley and Sons; 1977. p. 515.

4. Staessen JA, Fagard R, Thijs L, Celis H, Arabidze GG, Birkenhäger WH, et al. Randomised double-blind comparison of placebo and active treatment for older patients with isolated systolic hypertension. The Systolic Hypertension in Europe (Syst-Eur) Trial Investigators. Lancet 1997;350:757-64.

5. Dhar DN, Sharma RL, Bansal GC. Gastro-intestinal nematodes in sheep in Kashmir. Vet Parasitol 1982;11:271-7.

6. Bundy DA. Immunoepidemiology of intestinal helminthic infections. 1. The global burden of intestinal nematode disease. Trans R Soc Trop Med Hyg 1994;88:259-61.

7. Satyavati GV, Raina MK, Sharma M. Medicinal Plants of India. New Delhi, India: Indian Council of Medical Research; 1976. p. 201-6.

8. Rajeswari NR, Ramalakshmi S, Muthuchelian K. GC-MS Analysis of bioactive components from the ethanolic leaf extract of Canthium dicoccum (Gaertn.). J Chem and Pharm Res 2011;3:792-8.

9. Neelima M, Prasad GP, Sudarsanam G, Penchala PG, Jothi B. Ethnobotanical studies in rapur forest division of Nellore district in Andhra Pradesh. Life Sci Lealf 2011;11:333-45.

10. Santhan S, Janarthan M, Ali MZ. Evaluation of antidiabetic and nephroprotective activity of $95 \%$ ethanol extract of Canthium dicoccum whole plant by using albino rats. J Chem Pharm Sci 2013;6:218-22.

11. Gupta AK. Cyanotis axillaris. The IUCN Red List of Threatened Species; 2011.

12. Vidyarthi RD, Pandey PN. Textbook of Zoology. Vol. 14. New Delhi: Chand and Company; 2005. p. 329. 
13. Thorn GW, Adams RD, Brauwald EK, Isselbacher KJ, Petersdoft RG. Harrison's Principles of Internal Medicine. Vol. 10. New York: McGraw Hill and Company; 1977. p. 1088.

14. Harborne JB. Phytochemical Methods: A Guide to Modern Techniques of Plant Analysis. Vol. 3. Boca Raton: Chapman and Hall Publication; 1998. p. 11.

15. Jimsheena VK, Gowda LR. Colorimetric, high-throughput assay for screening Angiotensin I-converting enzyme inhibitors. Anal Chem 2009;81:9388-94.

16. Hooper NM, Turner AJ. Isolation of two differentially glycosylated forms of peptidyl-dipeptidase A (angiotensin converting enzyme) from pig brain: A re-evaluation of their role in neuropeptide metabolism. Biochem J 1987;241:625-33.

17. Thorn GW, Adams RD, Brauwald EK. Harrison's Principles of Internal Medicine. New York: McGraw Hill and Company; 1977. p. 1088.

18. Vigar Z. Atlas of Medical Parasitology. Vol. 2. Singapore: PG Publishing House; 1984. p. 216

19. Toker G, Kupeli E, Memizolu M, Yesilada EJ. Ethnopharmacol 2004;95:393.

20. Satyanarayana V, Kumari SJ. Preliminary phytochemical screening and antioxidant activity of selected four plants. Int J Green Pharm 2017;11:S116

21. Loizzo MR, Tundis R, Menichini F, Statti GA, Menichini F. Hypotensive natural products: Current status. Mini Rev Med Chem 2008;8:828-55.

22. Elbl G, Wagner H. A new method for the in vitro screening of inhibitors of angiotensin-converting enzyme (ACE), using the chromophore and fluorophore-labelled substrate, dansyltriglycine. Planta Med 1991;57:137-41.

23. Girirajasekhar D, Prasanna DG, Chandrakanth P. Prescribing pattern of antihypertensive drugs based on compelling indications with hypertension. Int J Pharm Pharm Sci 2016;8:72-5.

24. Shil D, Laloo D, Das SR, Dash S. Pharmacognostical and phytochemical standardization of Physalis minima L. Leaf. Int J Pharm Pharm Sci 2019;11:20-5.

25. Thompson DP, Geary TG. The structure and function of helminths surfaces. In: Marr JJ, editor. Biochemistry and Molecular Biology of Parasites. Cambridge: Academic Press; 1995. p. 203-32.

26. Iqbal Z, Sarwar M, Jabbar A, Ahmed S, Nisa M, Sajid MS, et al. Direct and indirect anthelmintic effects of condensed tannins in sheep. Vet Parasitol 2007;144:125-31. 